\title{
Plant Biostimulants: Importance of the Quality and Yield of Horticultural Crops and the Improvement of Plant Tolerance to Abiotic Stress-A Review
}

\author{
Magdalena Drobek, Magdalena Frąc and Justyna Cybulska *(i) \\ Institute of Agrophysics, Polish Academy of Sciences, Doświadczalna 4, 20-290 Lublin, Poland; \\ m.drobek@ipan.lublin.pl (M.D.); m.frac@ipan.lublin.pl (M.F.) \\ * Correspondence: j.cybulska@ipan.lublin.pl; Tel.: +48-81-744-5061
}

Received: 26 April 2019; Accepted: 20 June 2019; Published: 24 June 2019

check for updates

\begin{abstract}
Biostimulants are among the natural preparations that improve the general health, vitality, and growth of plants and protect them against infections. They can be successfully used in both agri- and horticultural crops. The main active substances used in such preparations are humic and fulvic acids, protein hydrolysates, compounds containing nitrogen, seaweed extracts, beneficial fungi, and bacteria. Biostimulant formulations may be single- or multi-component, but the synergic action of several different components has been observed. Many groups of biostimulants have been distinguished through their method of application (soil, foliar), the material from which they were produced (plant, animal), or the process by which they were created (hydrolysis, fermentation, extraction). Natural soil stimulants can induce the development of beneficial soil organisms that provide substrates for plant growth. The use of natural preparations that are not harmful to the environment is particularly important in connection with the progressive processes of soil degradation and atmospheric pollution. This review gives an overview of the importance and influence of different natural plant biostimulants on both the yield and quality of crops.
\end{abstract}

Keywords: fruit quality; plants biostimulants; yielding

\section{Introduction}

The quality and quantity of crops are influenced by both biotic and abiotic factors. Quality may be defined as a set of agronomic (e.g., fruit size, yield, resistance to bacteria and fungi) and organoleptic (e.g., colour, shape, firmness) properties as well as nutrient and vitamin content [1]. The abiotic factors include soil composition, extreme salinity, acidity, high and low temperatures, drought, pollution, humidity, rain, wind, or ultraviolet radiation. Stress caused by unfavourable stimuli can significantly reduce harvest yields because plants respond by using their energy reserves to fight stress instead of concentrating on yielding. Biotic factors include various bacteria, fungi, or viruses that are the cause of numerous plant diseases. Fungal and bacterial infections may not only reduce yield but may also lead to the loss of the entire harvest. To prevent this, various types of plant protection products are used. In accordance with the recommendations of the European Union [2], chemical and mineral plant protection agents are intended to be slowly replaced by natural preparations. The reason for this is the adverse influence of chemical and mineral plant protection agents on the natural environment, as well as on the health benefits of plant crops. Moreover, artificial fertilizers are responsible for the eutrophication of many bodies of water. This results in the formation of dead zones devoid of living organisms. The Baltic Sea alone is distinguished by having oxygen-free zones making up around $60,000 \mathrm{~km}^{2}$ of area caused by water pollution due to fertilizers. This area constitutes, on average, $3.5 \%$ of the catchment area of the Baltic Sea [3]. The effects of fertilizers have an unfavourable effect on algae, 
plants, animals, and people. Due to the fact that man is a higher-order consumer, people are particularly severely exposed to the harmful effects of fertilizer compounds accumulated at the lower levels of the food chain. Harmful compounds from fertilizers may weaken enzymes or interfere with protein production or vitamin absorption in the human body [3]. Natural preparations called biostimulants increase the efficiency of nutrient utilization and tolerance to abiotic stress and improve the quality of crops [4]. Biostimulants include organic and non-organic substances and/or microorganisms [5]. Farmers who manage organic farms are also eager to use natural stimulants to improve crop quality [6]. Increasing consumer awareness concerning healthy food favours the enhancement of the significance of organic farming [7].

The effects of the stimulators may be multifaceted. The effects of their activities vary depending on the type of biostimulant used and the plant variety. However, it should be noted that most of them have a beneficial effect on crops [8].

\section{Definitions and Classification of Biostimulants}

Biostimulants can be treated as an additive to fertilizers and support the uptake of nutrients, promote plant growth, and increase tolerance to abiotic stress [9]. The definition of biostimulants is wide and not sufficiently precise. However, there are two main features that distinguish biostimulants from other growth and plant-protection agents. A biostimulant may be any substance or mixture of substances of natural origin or microorganism which improves the condition of crops without causing adverse side effects [10].

Enzymes, proteins, amino acids, micronutrients, and other compounds may be used as biostimulants. Natural stimulants are often included under the term biostimulants, including phenols, salicylic acid, humic and fulvic acids, or protein hydrolases [10,11]. An important group of plant biostimulants are organisms including fungi and bacteria that change the species composition of organisms found in the soil or plants. Their presence may accelerate the rate of degradation processes or limit the number of specific fungal and bacterial groups [12,13]. Popular fungi used as biostimulants include Glomus intraradices [14], Trichoderma atroviride [14], Trichoderma reesei, and Heteroconium chaetospira [10,15-19]. Useful bacteria include Arthrobacter spp., Enterobacter spp., Acinetobacter spp., Pseudomonas spp., Ochrobactrum spp., Bacillus spp., and Rhodococcus spp. [18,19].

Biostimulants cannot be defined as fertilizers because they do not provide nutrients directly to plants. Biostimulants may facilitate the acquisition of nutrients by supporting metabolic processes in the soil and plants. An example of such an activity is the facilitation of the development of arbuscular mycorrhizal fungi that transport nutrients to the host plant [20].

\section{Sources of Biostimulants}

Biostimulants are preparations made from natural raw materials. Some of them are plant extracts such as rosemary, which stimulates the growth of tomato plants with a concentration of $1000 \mathrm{ppm}$. Rosemary oil contributes to improved nutrient uptake and increases the fresh mass of roots [21]. Plant and animal biostimulants are formed, for example, as a result of chemical or enzymatic hydrolysis. The products of hydrolysis are mixtures of peptides and amino acids (protein hydrolysates). Chemical acid or alkaline hydrolysis is used to produce biostimulants of animal origin, from raw materials such as hen feathers, bone meal, casein, collagen from skins, animal tissue or fish waste (Table 1). Biostimulants of plant origin are produced using enzymatic hydrolysis. In the production of plant biostimulants, for example, alfalfa hay, pulses, and vegetable or fruit waste may be used [13,22]. Protein hydrolysates contain amino acids, peptides, and non-protein compounds. Protein hydrolysates stimulate plant growth, reduce the use of inert fertilizers, and are environmentally friendly [22]. The solution, which at the same time allows for a reduction in the amount of organic waste and the creation of biostimulating preparations, is actually a fermentation process. Biostimulants may also be the products of anaerobic digestion (Table 1). Dissolved organic matter is formed in fermentation chambers and has stimulating properties. The source of dissolved organic matter is usually plant, animal, and lignin 
biomass [23]. Biopreparations from marine algae may contain low-molecular polypeptides and amino acids, vitamins, enzymes, phytohormones, sugars, and antioxidants. These compounds activate the processes of rhizogenesis and lead to positive morphological and anatomical changes in plants (Table 1). Two applications of a biopreparation derived from algae enhanced the development of Cornus alba "Aurea" roots by $80 \%$ when compared to the control. Such biopreparations can be used for rooting young seedlings or improving the process of adult rhizogenesis [24].

Literature data indicate the positive effect of seaweed extracts as plant biostimulants. The extracts from Ascophyllum nodosum are listed as the most frequently used $[25,26]$. Equally popular are Solanum lycopersicum L. [27], Ecklonia maxima, Sargassum spp. [12], Laminaria spp., Durvillaea potatumum, Ulva lactuca, Caulerpa sertularioides, Padina gymnospora, Sargassum liebmannii, and Sargassum johnstonii [25,28].

The group of biostimulants also includes consortia of beneficial fungi or bacteria. Among the fungi used in the cultivation of plants, the following species are noted: Glomus intraradices, Trichoderma atroviride, Trichoderma reesei, and Heteroconium chaetospira (Table 1) [10,14-17]. Symbiotic arbuscular mycorrhizal fungi have a positive effect on crop quality. Arbuscular mycorrhizal fungi, along with Rhizoglomus irregular, promote the growth of Stevia rebaudiana Bertoni [20]. Plant growth bacteria include Arthrobacter spp., Enterobacter spp., Acinetobacter spp., Pseudomonas spp., Ochrobactrum spp., Bacillus spp., and Rhodococcus spp. (Table 1) [18,19]. The largest group of beneficial bacteria includes Rhizobium spp. and plant growth-promoting rhizobacteria [10]. The plant growth-promoting rhizobacteria group includes Streptomyces spp., Pseudomonas spp., and Bacillus spp. The literature results indicate that Streptomyces spp. protect tomato plants against putrefactive bacteria Pectobacterium carotovorum subsp. brasiliensis $(\mathrm{Pcb})$. In addition, the volatiles produced by six Streptomyces spp. isolates stimulate the growth of tomato roots. The largest fresh root mass obtained due to the volatile substances was $138.2 \pm 16.1 \mathrm{mg}$ in comparison to a control mass of $111.5 \pm 10.3 \mathrm{mg}$. The volatile substances also positively affect the dry matter content and root volume as well as the dry and fresh mass of the shoot [29]. Zhao et al. [30] managed to isolate 276 endophytic bacteria from soybean root nodules that protected soybean roots against fungal infections of Phytophthora sojae. The antagonistic bacteria included Enterobacter spp., Acinetobacter spp., Pseudomonas spp., Ochrobactrum spp., and Bacillus spp. Also, lactic acid bacteria, e.g., Lactobacillus plantarum, and Lactobacillus paracasei are used to promote plant growth and indirectly control diseases [31].

Table 1. Activity of different types of biostimulants.

\begin{tabular}{|c|c|c|}
\hline Source of Biostimulant & Example & Main Activity \\
\hline Hydrolysis Product & $\begin{array}{l}\text { Enzymatic (alfalfa hay, pulses, and } \\
\text { vegetable or fruit waste) and } \\
\text { chemical (feathers, bone meal, } \\
\text { casein, collagen from skins, animal } \\
\text { tissue, or fish waste) }\end{array}$ & $\begin{array}{c}\text { Increase in yield [32] } \\
\text { Increase in nitrogen and phosphorus content in leaves } \\
\text { and macro- and micronutrients }[33,34] \\
\text { Increase in protein content in cereal grains [33] } \\
\text { Protection against biotic and abiotic stresses [35] } \\
\text { Increased soil fertility through the development of soil } \\
\text { microorganisms [36] }\end{array}$ \\
\hline $\begin{array}{c}\text { Anaerobic } \\
\text { Digestion Product }\end{array}$ & Plant, animal, and lignin biomass & $\begin{array}{c}\text { Call of the auxin-like effect }[23,37] \\
\text { Improving the availability of nutrients [31] }\end{array}$ \\
\hline $\begin{array}{l}\text { Biopreparations from } \\
\text { Marine Algae }\end{array}$ & $\begin{array}{l}\text { Ascophyllum nodosum, } \\
\text { Sargassum wightii, } \\
\text { Ecklonia maxima, } \\
\text { Enteromorpha intestinalis, } \\
\text { Gelidium pectinutum }\end{array}$ & $\begin{array}{c}\text { Antioxidant potential and ability to capture free } \\
\text { radicals [12] } \\
\text { Chelating effect [12] } \\
\text { Increase in plant resistance to fungal and bacterial } \\
\text { infections [12] } \\
\text { Extension of the shelf-life of fruit for consumption [12] } \\
\text { Improve the thermal resistance of plants [12] } \\
\text { Protection against drought stress [38] }\end{array}$ \\
\hline $\begin{array}{l}\text { Consortia of } \\
\text { Beneficial Fungi }\end{array}$ & $\begin{array}{l}\text { Rhizophagus intraradices, } \\
\text { Rhymbocarpus aggregatus, } \\
\text { Glomus viscosum, } \\
\text { Glomus etunicatum, } \\
\text { Glomus claroideum, } \\
\text { Trichoderma sp., } \\
\text { Heteroconium chaetospira }\end{array}$ & $\begin{array}{l}\text { Increase in the growth and yield of plants alone and in } \\
\text { symbiosis with bacteria, e.g., from Azotobacter spp. [39] } \\
\text { Plant protection against oxidative stress [40] }\end{array}$ \\
\hline
\end{tabular}




\section{Application Method of Biostimulants}

Biostimulants may be used in the form of soil preparations (powders, granules, or solutions added to the soil) or as liquid foliar application products [41]. Biostimulants containing humic substances and nitrogen compounds are often applied directly onto the soil, whereas various types of extracts from plants and seaweed are used in the form of foliar applications. Biostimulants can be introduced into the irrigation system and taken up by plants along with water. One example is the Kelpak SL (Ecklonia maxima extract) biostimulant which was sprayed in an aqueous solution of Phaseolus vulgaris L. [41]. Biostimulants are used regularly during the whole vegetative period or proactively, i.e., once during the decline of vital forces of the plant. In this case, the biostimulants were administered once during the occurrence of a strong stress factor, e.g., frost [42-44]. The results show that the soil application of the biostimulant was not as effective as foliar application. The foliar application of a biostimulant obtained from sewage sludge increased the level of macro- and micronutrients in the leaves of maize. The nitrogen content in maize leaves increased by $26 \%$ (dose $3.6 \mathrm{~L} / \mathrm{ha}$ ) and $46 \%$ (dose $7.2 \mathrm{~L} / \mathrm{ha}$ ) [45]. Biostimulants can also be used in the form of biomass or meal from seaweed, however, this method has some limitations. Biomass and meal may be used in areas located close to the source of seaweed acquisition due to transport problems. Biomass or meal is applied directly to the soil long before planting in order to enrich the substrate with nutrients. Agro-technical measures such as ploughing are used to mix biomass or meal with the topsoil [12].

Common forms in which biostimulants occur are ready-to-use extracts or powder to make an aqueous solution. Soil biostimulants often affect the structure of the root, increasing, among other factors, its ability to absorb nutrients. Foliar extracts protect the plant against biotic and abiotic stresses. The circadian rhythm of plants should be taken into consideration. Biostimulants should be applied in the morning when the stomata are open and the assimilation rate is at its peak [12,38]. Biostimulants are also applied directly onto harvested fruits. It was noted that biostimulants containing a combination of extracts from Sargassum spp., Laminaria spp., and A. nodosum (Table 1) significantly extended the shelf-life and the storage life of oranges. After using the biostimulant, the fruits became more resistant to mechanical damage and putrefaction which allowed for an extension of the storage time and suitability for consumption. The extract used produced a better effect than, for example, the calcium chloride normally used in the industry to protect fruit against putrefactive bacteria [12,38].

\section{Effect of Biostimulants on Yielding}

The popularity of biostimulants in agriculture is associated with the possibility of obtaining higher yields without the need to discontinue the production of ecological crops. According to numerous scientific studies, biostimulants have a positive effect on yielding plants [36]. The yield is usually determined as the amount of fruit obtained from one plant or plot. The yield depends on the type of biostimulant used, the dose, the method of application, and the plant variety. Increased yield is often associated with improving the quality of vegetables or fruit. This is particularly important in organic farming, where artificial fertilizers cannot be used $[37,45]$. The quality of fruits and vegetables is shaped from the moment of plant growth to the time of harvesting of fruits and vegetables and it consists of the taste and the content of nutrients. The quality is influenced by genetic and agro-environmental factors [46].

The positive influence of biostimulants based on humic, fulvic, and carboxylic acids on the yielding of apricot fruits has been proven [8]. Control trees showed a yield of $12 \mathrm{~kg}$ fruit/tree and after the application of humic and fulvic acids together and carboxylic acids in a separate experiment, the yield of the trees increased to $21 \mathrm{~kg}$ of fruit/tree and $19 \mathrm{~kg}$ of fruit/tree, respectively (Table 2). However, this relationship was observed only in the second year of using the biostimulant. During the first growing season, the yield of the control trees was higher than that of the trees that were treated with biostimulants containing humic and fulvic acids. The biostimulant based on polysaccharides turned out to be ineffective with this variety of apricot trees, which showed a yield comparable to the control in both growing seasons [8]. Preparations containing all amino acids allowed for an increase in mango 
yield. With a dose of $3 \mathrm{~L} / \mathrm{ha}$, the yield increased by $18 \%$ compared to the control. At the same time, the biostimulants caused a 15\% decrease in fruit weight. The authors explained this phenomenon through the competition of fruit for nutrients [32]. Biostimulants containing phenolic compounds such as sodium para-nitrophenolan, sodium orto-nitrophenolan, and sodium 5-nitroguajakolan proved to be good preparations for raspberry bushes. As a result of the foliar application of the phenolic compounds, a 20\% (Table 2) increase in raspberry yield was obtained [47]. The highest yield was achieved when a biostimulant containing phenol compounds was applied to the "Polka" raspberry variety (yield $=23.03 \mathrm{~kg} / \mathrm{plot}$ ), while the yield in the control was $18.28 \mathrm{~kg} / \mathrm{plot}$. Already in the first year after the use of biostimulants, the amount of fruit collected from one bush increased. The best results were produced by 6-benzyladenine in a dose of $100 \mathrm{mg} / \mathrm{L}$, which caused an increase in yield in the first year by about $0.5 \mathrm{~kg}$. In the second year of using the biostimulant 6-benzyladenine at a dose of $100 \mathrm{mg} / \mathrm{L}$ and $\alpha$-naphthaleneacetic acid at a dose of $20 \mathrm{mg} / \mathrm{L}$, the yield increased by more than $1 \mathrm{~kg}$ from a single shrub [37]. Strawberry yielding significantly increased after using biostimulants containing herbal and marine plant extracts. In this case, the study proved that soil biostimulants are a source of nitrogen compounds. Moreover, foliar biostimulant application did not produce results as good as biostimulants added to the soil. Biostimulants added to the soil caused a significant increase in the amount of fruit and also improved the condition of the plants. Plants were more resistant to weather conditions and pathogens [42]. Extracts of "Moscatel" vine-shoots improved the yielding of the grapevine variety "Airén". The literature results indicate that two foliar biostimulant variants were prepared, non-toasted and toasted vine-shoots. A significantly higher yield was achieved in the case of two preparations, which were the non-toasted vine-shoots extract $(3.09 \pm 0.05 \mathrm{~kg} / \mathrm{plant})$ and the toasted vine-shoots extract $(3.57 \pm 0.05 \mathrm{~kg} / \mathrm{plant})$ in comparison to the control $(2.54 \pm 0.03 \mathrm{~kg} / \mathrm{plant})$ (Table 2) [48].

A mixture of four biostimulants containing amino acids, polysaccharides, vitamins, humic acids, organic carbon, and enzymatic proteins caused a comparable increase in the yield of two varieties of yellow pepper [49]. The Blondy F1 variety produced a crop at a level of 5.98a $0.23 \mathrm{~kg} / \mathrm{plot}$ (yield $=5.24 \pm 0.30 \mathrm{~kg} / \mathrm{plot}$ ). The Century F1 variety produced a yield of $5.76 \pm 0.20 \mathrm{~kg} / \mathrm{plot}$ (yield in the control $=5.06 \pm 0.28 \mathrm{~kg} / \mathrm{plot}$ ) (Table 2). The peptides and amino acids contained in these formulations demonstrated a protective action against excessively high temperatures in the summer season and induced root growth and development, while vitamins and humic acids resulted in fruit growth [49]. Horseradish extract increased pumpkin yield by $12.5 \%$ [50] and the beneficial effect of fungal species Glomus intraradices and Trichoderma atroviride positively influenced the yielding of zucchini, resulting in a yield increase of $0.39 \mathrm{~kg}$ per plant on average, probably by increasing the effectiveness of nutrients uptake [14]. A 3\% Moringa oleifera extract in combination with $0.6 \% \mathrm{ZnSO}_{4}$ and $0.25 \% \mathrm{~K}_{2} \mathrm{SO}_{4}$ increased the yield of "Kinnow" mandarin plants by $65 \%$ (Table 2) compared to the control [51].

The results of the study underline the positive effect of humic acids on the yielding of fruit trees [8]. The use of phenolic compounds [47] resulted in the increased yielding of fruit bushes. A high yield of vegetables may be obtained by using a mixture of amino acids, polysaccharides, vitamins, humic acids, and other compounds. Each of the substrates of the mixture affects another biochemical process occurring in the soil and plant, which allows for the achievement of the desired effect [49]. 
Table 2. Effect of selected biostimulants on quality of fruit and vegetables.

\begin{tabular}{|c|c|c|c|c|}
\hline Biostimulant & Dose & Plant & Type of Claims & Benefitial Effect \\
\hline Humic and fulvic acids & $500 \mathrm{~g} / 100 \mathrm{~L}$ & $\begin{array}{c}\text { Apricot } \\
\text { (Prunus armeniaca L.) }\end{array}$ & Yield & Increase by $75 \%$ in the second year compared to the control [8] \\
\hline Carboxylic acids & $200 \mathrm{~mL} / 100 \mathrm{~L}$ & $\begin{array}{c}\text { Apricot } \\
\text { (Prunus armeniaca L.) }\end{array}$ & Yield & Increase $58 \%$ in the second year compared to the control [8] \\
\hline All amino acids & $3 \mathrm{~L} / \mathrm{ha}$ & $\begin{array}{c}\text { Mango } \\
\text { (Mangifera indica) }\end{array}$ & Yield & Increase by $18 \%$ compared to the control [32] \\
\hline 6-benzyladenine & $100 \mathrm{mg} / \mathrm{L}$ & $\begin{array}{c}\text { Blueberry } \\
\text { (Vaccinium corymbosum L.) }\end{array}$ & Yield & $\begin{array}{l}\text { Increase by } 0.5 \mathrm{~kg} / \text { tree in the first year of using the biostimulant compared to } \\
\text { the control [37] }\end{array}$ \\
\hline $\begin{array}{l}\alpha \text {-naphthaleneacetic acid and } \\
\text { 6-benzyladenine }\end{array}$ & $\begin{array}{l}100 \mathrm{mg} / \mathrm{L} \text { ( } \alpha \text {-naphthaleneacetic acid }) \\
20 \mathrm{mg} / \mathrm{L} \text { (6-benzyladenine) }\end{array}$ & $\begin{array}{c}\text { Blueberry } \\
\text { (Vaccinium corymbosum L.) }\end{array}$ & Yield & $\begin{array}{l}\text { Increase by } 1 \mathrm{~kg} / \text { tree in the second year of using the biostimulant compared } \\
\text { to the control [37] }\end{array}$ \\
\hline Humic acids & $3 g / L$ & $\begin{array}{c}\text { Cucumber } \\
\text { (Cucumis sativus L.) }\end{array}$ & Diameter & $\begin{array}{l}\text { Increase in vegetable diameter by } 1.23 \mathrm{~cm} \text { (first season) and } 1.55 \mathrm{~cm} \text { (second } \\
\text { season) compared to the control [52] }\end{array}$ \\
\hline Nitrogen, amino acids, auxins & $0.45 \mathrm{~cm} / \mathrm{L}$ & $\begin{array}{c}\text { Cucumber } \\
\text { (Cucumis sativus L.) }\end{array}$ & Length & $\begin{array}{l}\text { Lengthening vegetables by } 3.85 \mathrm{~cm} \text { (first season) and } 3.49 \mathrm{~cm} \text { (second season) } \\
\text { compared to the control [52] }\end{array}$ \\
\hline Biostimulant & Dose & Plant & Type of Claims & Benefitial Effect \\
\hline Carboxylic acids & $200 \mathrm{~mL} / 100 \mathrm{~L}$ & $\begin{array}{c}\text { Apricot } \\
\text { (Prunus armeniaca L.) }\end{array}$ & Diameter & $\begin{array}{l}\text { Increase diameter by } 2.6 \mathrm{~mm} \text { (second growing season) compared to the } \\
\text { control [8] }\end{array}$ \\
\hline $\begin{array}{l}\text { Arbuscular mycorrhizal fungi } \\
\text { and Pseudomonas fluorescens C7 }\end{array}$ & $\begin{array}{l}\text { The bacterial inoculum was } \\
\text { replicated, watering each plant with } \\
200 \mathrm{~mL} \text { of bacterial suspension } \\
\text { (density about } 108 \text { colony forming } \\
\text { unit CFU/mL) }\end{array}$ & $\begin{array}{c}\text { Tomato } \\
\text { (Solanum lycopersicum L.) }\end{array}$ & Weight & Increase in tomato fruit mass by $6.9 \mathrm{~g}$ compared to control [53] \\
\hline 6-benzyladenine & $100 \mathrm{mg} / \mathrm{L}$ & $\begin{array}{l}\text { Blueberry cv. Duke and } \\
\text { Bluecrop }\end{array}$ & Weight & $\begin{array}{l}\text { Increase in the weight of blueberry fruit by about } 32.4 \% \text { (first season) and } \\
33.6 \% \text { (second season) for the blueberry cultivar Duke and } 43.5 \% \text { (first } \\
\text { season) and 33.1\% (second season) for the blueberry cultivar Bluecrop } \\
\text { compared to the control [53] }\end{array}$ \\
\hline$\alpha$-naphthaleneacetic acid & $20 \mathrm{mg} / \mathrm{L}$ & $\begin{array}{l}\text { Blueberry cv. Duke and } \\
\text { Bluecrop }\end{array}$ & Weight & $\begin{array}{l}\text { Increased the weight of the blueberry cultivar Duke fruit by } 41.9 \% \text { (first } \\
\text { season) and } 20.0 \% \text { (second season) and the blueberry cultivar Bluecrop by } \\
55.0 \% \text { (first season) and } 25.4 \% \text { (second season) compared to the control [37] }\end{array}$ \\
\hline Humic Acids & $3 g / L$ & $\begin{array}{c}\text { Cucumber } \\
\text { (Cucumis sativus L.) }\end{array}$ & Length & $\begin{array}{l}\text { Increase in vegetable diameter by } 1.23 \mathrm{~cm} \text { (first season) and } 1.55 \mathrm{~cm} \text { (second } \\
\text { season) compared to the control [52] }\end{array}$ \\
\hline Nitrogen, amino acids, auxins & $0.45 \mathrm{~cm} / \mathrm{L}$ & $\begin{array}{c}\text { Cucumber } \\
\text { (Cucumis sativus L.) }\end{array}$ & Length & $\begin{array}{l}\text { Lengthening vegetables by } 3.85 \mathrm{~cm} \text { in the first and } 3.49 \mathrm{~cm} \text { in the second } \\
\text { growing season compared to the control [52] }\end{array}$ \\
\hline
\end{tabular}


Table 2. Cont.

\begin{tabular}{|c|c|c|c|c|}
\hline Carboxylic acids & $200 \mathrm{~mL} / 100 \mathrm{~L}$ & $\begin{array}{c}\text { Apricot } \\
\text { (Prunus armeniaca L.) }\end{array}$ & Diameter & $\begin{array}{l}\text { Widening of fruit by } 2.6 \mathrm{~mm} \text { on average in the second growing season } \\
\text { compared to the control [8] }\end{array}$ \\
\hline $\begin{array}{l}\text { Arbuscular mycorrhizal fungi } \\
\quad \text { and P. fluorescent } \mathrm{C} 7\end{array}$ & $\begin{array}{l}\text { The bacterial inoculum was } \\
\text { replicated, watering each plant with } \\
200 \mathrm{~mL} \text { of bacterial suspension } \\
\text { (density about } 108 \mathrm{CFU} / \mathrm{mL} \text { ) }\end{array}$ & $\begin{array}{c}\text { Tomato } \\
\text { (Solanum lycopersicum } \mathrm{L} .)\end{array}$ & Weight & Increase in tomato fruit mass by $6.9 \mathrm{~g}$ compared to control [53] \\
\hline 6-Benzyladenine & $100 \mathrm{mg} / \mathrm{L}$ & $\begin{array}{l}\text { Blueberry cv. Duke and } \\
\text { Bluecrop }\end{array}$ & Weight & $\begin{array}{c}\text { Increase in the weight of blueberry fruit by about } 32.4 \% \text { (first season) and } \\
33.6 \% \text { (second season) for the blueberry cultivar Duke and } 43.5 \% \text { (first } \\
\text { season) and 33.1\% (second season) for the blueberry cultivar Bluecrop } \\
\text { compared to the control [53] }\end{array}$ \\
\hline$\alpha$-naphthaleneacetic acid & $20 \mathrm{mg} / \mathrm{L}$ & $\begin{array}{l}\text { Blueberry cv. Duke and } \\
\text { Bluecrop }\end{array}$ & Weight & $\begin{array}{l}\text { Increase in weight of the blueberry cultivar Duke fruit by } 41.9 \% \text { (first season) } \\
\text { and } 20.0 \% \text { (second season) and the blueberry cultivar Bluecrop by } 55.0 \% \\
\text { (first season) and } 25.4 \% \text { (second season) compared to the control [46] }\end{array}$ \\
\hline $\begin{array}{l}\text { Biostimulant including, among } \\
\text { others, nitrogen, amino acids, } \\
\text { auxins }\end{array}$ & $0.45 \mathrm{~cm} / \mathrm{L}$ & $\begin{array}{c}\text { Cucumber } \\
\text { (Cucumis sativus L.) }\end{array}$ & Plant height & $\begin{array}{l}\text { Increase in plant height of } 14.5 \mathrm{~cm} \text { (in the first growing season) and } 19.75 \mathrm{~cm} \\
\text { (in the second growing season) in comparison with the control plants [52] }\end{array}$ \\
\hline Moringa oleifera leaf extract & $\begin{array}{l}\begin{array}{l}3 \% \text { treatments were replicated three } \\
\text { times }\end{array} \\
\text { t }\end{array}$ & Pumpkin (Cucurbita pepo L.) & Chlorophyll content & $34.6 \%$ increase in the chlorophyll content compared to the control [50] \\
\hline $\begin{array}{l}\text { Salicylic acid-chitosan } \\
\text { nanoparticles }\end{array}$ & (concentration $0.01 \%-0.16 \%$ ) & Maize CV. Surya local & Chlorophyll content & $\begin{array}{l}\text { Chlorophyll content in the control was } 10.72 \mathrm{mg} / \mathrm{g} \text {, the chlorophyll content in } \\
\text { the maize leaves treated with the biostimulant (concentration } 0.01 \%-0.16 \% \text { ) } \\
\text { was in the range of } 16.43 \text { to } 25.88 \mathrm{mg} / \mathrm{g} \text { on average [ } 54]\end{array}$ \\
\hline $\begin{array}{l}\text { Ascophyllum nodosum Seaweed } \\
\text { Extract }\end{array}$ & $1.5 \mathrm{~kg} / \mathrm{ha}$ & "Sangiovese" grapes & Phenolic content & Phenolic content increased by $1.063 \mathrm{mg} / \mathrm{cm}^{2}$ compared to the control [55] \\
\hline A. nodosum Seaweed Extract & $3 \mathrm{~kg} / \mathrm{ha}$ & "Sangiovese" grapes & Phenolic content & Phenolic content increased by $0.951 \mathrm{mg} / \mathrm{cm}^{2}$ compared to the control [55] \\
\hline $\begin{array}{l}\text { Biostimulant (chicken feathers) } \\
\text { with Fertilizer (300 kg N/ha + } \\
120 \mathrm{~kg} \mathrm{~K} / \mathrm{ha})\end{array}$ & $3.6 \mathrm{~L} / \mathrm{ha}$ & $\begin{array}{l}\text { Maize (Zea mays L. cv } \\
\text { PR32W86 Pioneer) }\end{array}$ & Nitrogen content & $\begin{array}{l}\text { Nitrogen content of corn leaves increased by } 14.4 \% \text { (first season) } \\
15 \% \text { (second season) compared to the control [33] }\end{array}$ \\
\hline $\begin{array}{l}\text { Biostimulant (chicken feathers) } \\
\text { with fertilizer ( } 300 \mathrm{~kg} \text { N/HA + } \\
\qquad 120 \mathrm{~kg} \mathrm{~K} / \mathrm{HA})\end{array}$ & $7.2 \mathrm{~L} / \mathrm{ha}$ & $\begin{array}{l}\text { Maize (Zea mays L. cv } \\
\text { PR32W86 Pioneer) }\end{array}$ & Nitrogen content & $\begin{array}{l}\text { Increase nitrogen content by } 39.1 \% \text { (first season) and } \\
33.3 \% \text { (second season) compared to the control [33] }\end{array}$ \\
\hline Protein hydrolysate & 5.0 and $2.5 \mathrm{~mL} / \mathrm{L}$ & $\begin{array}{c}\text { Tomato } \\
\text { (Solanum lycopersicum } \mathrm{L} . \text { ) }\end{array}$ & Content of lycopene & Increased by $34.9 \%$ and $18.0 \%$, respectively, compared to the control [3] \\
\hline Protein hydrolysate & $2.5 \mathrm{~mL} / \mathrm{L}$ & $\begin{array}{c}\text { Tomato } \\
\text { (Solanum lycopersicum } \mathrm{L} . \text { ) }\end{array}$ & Ascorbic acid & Increase ascorbic acid content by $27.3 \%$ compared to the control [3] \\
\hline $3 \%$ corn seed extract & $\begin{array}{l}\text { Soaking and praying } \\
1 \mathrm{mM} \text { mg plants }\end{array}$ & $\begin{array}{l}\text { Sunflower seed } \\
\text { (Helianthus annuus L.) }\end{array}$ & $\begin{array}{l}\text { Enzymatic activity of } \\
\text { superoxide dismutase, } \\
\text { catalase, } \\
\text { and peroxidase }\end{array}$ & $\begin{array}{l}\text { Enzymatic activity of superoxide dismutase, catalase and peroxidase } \\
\text { increased by } 65.5 \%, 77.8 \% \text {, and } 84.6 \% \text {, respectively, as compared to the } \\
\text { controls [56] }\end{array}$ \\
\hline
\end{tabular}




\section{Effect of Biostimulants on the Growth and Size of Plants}

The way in which biostimulants work may be defined as multifaceted. The literature describes the positive effect of biostimulants on the growth of fruits and vegetables. At the same time, there are studies in which no effect of biostimulants on fruit size was found. The lack of biostimulant effects is explained by the use of a biostimulant unsuitable for the tested cultivar $[37,53]$.

Fruit producers are interested in biopreparations that allow for the attainment of the largest and healthiest-looking fruit that draw consumers' attention [52]. An increase in the average length and diameter of cucumbers was attained after the use of humic acids and a mixture of nitrogen, amino acids, and auxins. Humic acids in a concentration of $3 \mathrm{~g} / \mathrm{L}$ increased the average length of the fruit in the first and second season by $9.9 \mathrm{~cm}$ and $12.2 \mathrm{~cm}$, respectively. The same concentration of humic acids increased the diameter of the cucumbers in the first and second season by an average of $1.23 \mathrm{~cm}$ and $1.55 \mathrm{~cm}$, respectively [52]. Three tested biostimulators caused an elongation and increase in the diameter of the vegetables. One biostimulant (containing nitrogen, amino acids, and auxins) led to the elongation of the cucumbers by $3.85 \mathrm{~cm}$ in the first and $3.49 \mathrm{~cm}$ in the second growing season. The diameter of the fruit increased by $1.12 \mathrm{~cm}$ and $1.56 \mathrm{~cm}$, respectively, in the first and second growing season under the influence of this biostimulant. The application of humic acids and biostimulants containing auxins in particular makes it possible to obtain elongated and thickened cucumbers [52]. The use of biostimulants containing humic and fulvic acids as well as carboxylic acids led to a tenfold enlargement of the apricot fruit. The greatest influence on the size of the fruit was carboxylic acids, which contributed to the widening of fruit by $2.6 \mathrm{~mm}$ on average in the second growing season [8].

Studies show that the perfect biostimulants that cause the growth of fruits and vegetables are consortia of microorganisms. Examples are arbuscular mycorrhizal fungi and plant growth-promoting bacteria, the use of which resulted in increased tomato weight. A positive effect was obtained through the combination of arbuscular mycorrhizal fungi containing fungi of the following species: Rhizophagus spp., Rhizophagus aggregatus, Septoglycus viscosum, Claroideoglomus etunicatum, Claroideoglomus claroideum and various types of plant growth-promoting bacteria. All of the biostimulants based on microorganisms (arbuscular mycorrhizal fungi + Pseudomonas sp. Strain 19Fv1T, arbuscular mycorrhizal fungi + Pseudomonas fluorescens C7, arbuscular mycorrhizal fungi + Pseudomonas sp. 19 Fv1T and Pseudomonas fluorescens (7) caused an increase in tomato fruit mass, but the most effective result was demonstrated by biostimulants including arbuscular mycorrhizal fungi and $P$. fluorescent $\mathrm{C}$, which caused an increase in tomato mass to $71.3 \pm 0.6 \mathrm{~g}$ (weight of control tomatoes $=64.4 \pm 0.9 \mathrm{~g}$ ). The microorganisms used caused a slight elongation of tomatoes as well. The length of the fruit in the controls ranged from $5.49 \pm 0.03 \mathrm{~cm}$ to $5.81 \pm 0.03 \mathrm{~cm}$, while in combination with the biostimulants used, it rose to $5.88 \pm 0.03 \mathrm{~cm}$ to $6.05 \pm 0.02 \mathrm{~cm}$. There was also a slight increase in fruit diameter from $4.24 \pm 0.02 \mathrm{~cm}$ to $4.62 \pm 0.03 \mathrm{~cm}$ to $4.64 \pm 0.03 \mathrm{~cm}$ to $4.78 \pm 0.02 \mathrm{~cm}$ [53].

The application of 6-benzyladenine as a biostimulant at a dose of $100 \mathrm{mg} / \mathrm{L}$ resulted in an increase in the weight of blueberry fruit by about $32.4 \%$ (first season) and $33.6 \%$ (second season) for the blueberry cultivar Duke and $43.5 \%$ (first season) and $33.1 \%$ (second season) for the blueberry cultivar Bluecrop compared to the control. The literature results showed that $\alpha$-naphthaleneacetic acid at a dose of $20 \mathrm{mg} / \mathrm{L}$ was also an effective biostimulant, which increased the weight of the blueberry cultivar Duke fruit by $41.9 \%$ (first season) and $20.0 \%$ (second season) and the blueberry cultivar Bluecrop by $55.0 \%$ (first season) and $25.4 \%$ (second season). As demonstrated in the study, one inefficient biostimulant was gibberellic acid at a dose of $200 \mathrm{mg} / \mathrm{L}$. Gibberellic acid increased the weight of blueberry cultivar Duke fruit by $4.7 \%$ (first season) and $14.3 \%$ (second season) as well as Bluecrop blueberry cultivar by $0.8 \%$ (first season) and $11.5 \%$ (second season) compared to the control. For this reason, gibberellic acid is not recommended as a biostimulant for soft fruits [37].

The titanium compounds with which raspberries were treated caused an increase in fruit weight from $4.44 \mathrm{~g}$ (control) to an average of $5.4 \mathrm{~g}$, but only at the beginning of the harvest season. At the end of the harvest, a 57\% decrease in raspberry weight was observed [47]. The same relationship was observed for phenolic compounds. At the beginning of the harvest, the mass of raspberries treated 
with phenolic compounds was $5.04 \mathrm{~g}$ on average, while at the end of the harvest there was a $44.4 \%$ loss in fruit weight. The fact is that the raspberry collection is characterized by the loss of fruit mass at the end of the harvest, but if these three biostimulants were used, the resulting losses were greater than in the control. The control fruits were characterized by a $42.3 \%$ weight loss, while the fruits treated with biostimulants showed a mass loss at the end of the harvest in the range from $44.4 \%$ to $57.0 \%$ [47]. The increase in fruit weight after the use of biostimulants compounds was also observed in the case of cherries. The use of salicylic acid with the addition of calcium resulted in a $15 \%$ increase in sour cherries "Sweetheart" (2015) and "Skeena" (2016) [57].

Regarding the multifaceted effect of biostimulants, it should be emphasized that these formulations may affect many of the characteristics of the plant, e.g., fruit size, plant height, and root length [52]. The use of humic acids in a concentration of $3 \mathrm{~g} / \mathrm{L}$ and other biostimulants caused an increase in cucumber plant height, the number of leaves, and the number of stems in both growing seasons [52]. In the first growing season, the height of the control plants was $78.13 \mathrm{~cm}$. Plants treated with $3 \mathrm{~g} / \mathrm{L}$ of humic acids were $14.25 \mathrm{~cm}$ taller on average. In the second growing season plants treated with humic acids were taller by $13.25 \mathrm{~cm}$. Similar dependencies may be observed after using other biostimulators. In the first and second growing season, this biostimulant (including, among others, nitrogen, amino acids, and auxins) was the most effective, causing an increase in plant height of $14.5 \mathrm{~cm}$ (in the first growing season) and $19.75 \mathrm{~cm}$ (in the second growing season) in comparison with the control plants. The biostimulant including, among others, naphthyl acetic acid was the least effective, and resulted in an increase in the growth of plants by $4.38 \mathrm{~cm}$ and $7.92 \mathrm{~cm}$, respectively to the first and second growing seasons. Similar dependencies were noted in the number of leaves and new stems [52].

\section{Impact of Biostimulants on Physical Characteristics}

Biostimulants also have an influence on mechanical properties, i.e., the firmness of fruits or vegetables. Depending on the type, biostimulants may cause the stiffening of cell walls, thereby reducing their extensibility [8]. Biostimulants that increase the flexibility of cell walls at the same time extend the shelf-life of fruits and vegetables for consumption and facilitate their storage. Biostimulants based on carboxylic, humic, and fulvic acids and also the biopolymers of polysaccharides increased the mechanical strength of apricot fruits during two years of biostimulant use [8]. In turn, biostimulants containing phenolic compounds or chitosan resulted in the loss of fruit firmness of the three raspberry varieties studied. The use of biostimulants based on titanium compounds did not alter the fruit firmness, which was comparable to the firmness in the control test [47]. The use of spic cytozyme containing essential plant nutrients and growth biostimulants in the amount of $4 \mathrm{~mL} / \mathrm{L}$ significantly reduced the cracking of pomegranate fruit [58]. In addition to improving mechanical properties, biostimulants change the shape and colour of fruits and vegetables. Fruit with larger length and diameter, as well as the right colours, are preferred by consumers [8]. However, consumer preferences are subject to dynamic changes.

An important visual feature that proves the quality of fruit is colour. The colour of the fruit is substantially influenced by the content of anthocyanins. Weber et al. [59] examined the content of anthocyanins in strawberries treated with Ascophyllum nodosum extract with silicon. Fruits treated with a biostimulator were characterized by a higher content of anthocyanins in the initial fruiting period, therefore, they were more red than the control fruits [59]. "Sweetheart" cherries treated with glycine and betaine were characterized by a darker skin than the control fruits. Although the mechanism of action of betaine and glycine on the formation of anthocyanins is not fully understood, it is known that the darker colour of the fruit was caused by a higher content of antioxidants [57]. Tarantino et al. (2018) in the second year of using biostimulants obtained apricot fruits with a lighter skin compared to the first year. This could be due to the higher concentration of biostimulants used in the first growing season. There were significant differences in the colour of the fruit. In the second year of the experiment the colour of the apricots was redder than in the first year of fruiting. There were no significant differences 
in the colour of the fruit produced by the three biostimulants used (1-biopolymers of polysaccharides; 2-humic and fulvic acids; 3 -carboxylic acids) [8].

It should be emphasized that the increased mechanical strength or fruit colour change results from the good condition of fruit plants, which in turn is a result of their proper nutrition [50]. Biostimulants are supplied externally, which indirectly, e.g., induced by the photosynthesis process, plays an important role in the nutrition of plants. Indirect induction, for example, consists in increasing the leaf area. Leaves are the main organs in which photosynthesis takes place, therefore increasing the leaf area leads to an increase in photosynthesis. Intensively photosynthetic plants are better nourished. Increasing the leaf area also leads to an increase in the transpiration surface. This phenomenon has the especially important function of protecting the plant from overheating. Moringa oleifera leaf extract increased the surface area of the Cucurbita pepo L. by $9.7 \%$ and simultaneously led to a $34.6 \%$ increase in the chlorophyll content of the leaves compared to the control [50]. The positive effect of the A. nodosum extract in a period of drought on the growth of spinach has been proven. Seaweed extract increased the relative water content of the leaves from $76 \%$ to $82 \%$. The surface area of the leaf was also increased by $16 \%$ (foliar spray), $21 \%$ (biostimulant in the irrigation system), and $38 \%$ (biostimulant in the irrigation system and in a spray). Increasing the area and turgor of the leaf led to an increase in the intensity of photosynthesis and improved the conditions for growing spinach under stress conditions [25].

\section{Effect of Biostimulants on Chemical Composition}

Biostimulants can affect a number of the chemical properties of fruits and vegetables, including dry mass, acidity or vitamin content. The chemical composition of the fruit directly affects their palatability. It is assumed that fruits with a content of dissolved solids (SSC) above $12^{\circ}$ Brix are characterized by an excellent taste [47]. In the first year of using biostimulants containing the biopolymers of polysaccharides, humic and fulvic acids as well as carboxylic acids, the average value of SSC in apricots stood at $10.7^{\circ}$ Brix. In the second year of using these biostimulants, fruit taste values improved significantly, as evidenced by the increase in the SSC level to an average of $14.1^{\circ}$ Brix [8]. Biostimulants containing phenol compounds or chitosan reduced the dissolved solids content in the fruits of the three raspberry varieties (Pokusa, Polka, and Poranna Rosa). The opposite effect was produced by biostimulants based on titanium compounds, the use of which resulted in an increase in the content of dissolved solids in the raspberry fruit [47]. The quality of the fruit is also demonstrated by the ratio content of dissolved solids to their titratable acidity. Fruit quality is defined as good if the ratio content of dissolved solids to titratable acidity is within the range of 10 to 15 . The treatment of fruit trees with biostimulants containing biopolymers of polysaccharides (16.7) and humic and fulvic acids (16.1) leads to an increase in the ratio content of dissolved solids to titratable acidity in relation to the control (14.0) and thus negatively influenced the sensory quality of fruit [8].

It is important to grow fruit that has an appropriate level of acidity but it is difficult to say, however, whether changes in acidity at the level of several percent have a significant impact on the fruit taste, because it is based on the subjective impression of the consumer. Although the literature data present studies on the effect of biostimulants on fruit acidity, there is no explicit interpretation of the results. It is not clear whether the changes in fruit acidity should be understood in terms of the positive or negative effects of the biostimulants used. The use of phenolic compounds and titanium compounds as a biostimulant in the cultivation of raspberries led to an increase in fruit acidity to $2.26 \%$ and $2.18 \%$, respectively (control, 2.08\%) [47]. A decrease in apricot acidity was noted after the use of biostimulants containing polysaccharides, humic and fulvic acids, and carboxylic acids [8]. In the second year after using these biostimulants, fruit acidity was reduced from an average of 3.45 (control $\mathrm{pH}$ ) to an average of 3.7-3.8 ( $\mathrm{pH}$ after using biostimulants) [8].

An important health-related feature of fruits and vegetables is the content of vitamin $C$ and nitrogen compounds. The role of nitrogen in plants results from its influence on growth and development. It is a component of nucleic acids, it participates in the process of photosynthesis, and it builds amino acids that form a part of plant proteins [60]. The content of vitamin C and nitrogen compounds in the fruit 
depends mainly on the plant variety [47]. The use of selected biostimulants (phenolic compounds, chitosan, and titanium compounds) increased both the levels of ascorbic acid and nitrates. It turned out that the three biostimulators tested positively influenced the level of nitrates in raspberries. It was found that phenolic compounds contained in one of the biostimulants increased the level of vitamin $C$ most effectively [47]. Assuming that phenolic compounds increased the content of vitamin $C$ in fruit, it was necessary to determine how different biostimulators affect the content of phenolic compounds. Zarzecka et al. [61] studied the effect of herbicides and biostimulators on the polyphenol content of potato tubers. The experiment was conducted over a period of two years. Three potato varieties were treated with different substances: Harrier herbicide 295 ZC, Harrier 295 ZC + Kelpak SL growth regulator, and Sencor 70 WG herbicide, 5 Sencor 70 WG + Asahi growth regulator. In the case of Asahi, the active substances were phenolic compounds, while for Kelpak SL, auxins and cytokinins were the active substances. The applied biostimulants and herbicides caused an increase in the polyphenol content in tubers of all potato varieties (on average, $159.8-161.3 \mathrm{mg} / \mathrm{kg}$ ) compared to the control (average of $156.0 \mathrm{mg} / \mathrm{kg}$ ). The use of biostimulants and herbicides increased the content of polyphenols in the leaves of the potato to an average of $289.2-291.2 \mathrm{mg} / \mathrm{kg}$ compared to the control $(287.8 \mathrm{mg} / \mathrm{kg})$. The content of polyphenols in tubers is of particular importance for humans. Polyphenols reduce the risk of numerous diseases, e.g., blocking carcinogenic compounds [61]. It was observed that after using a biostimulant containing seaweed A. nodosum and silicon, the content of phenolic compounds in strawberries was slightly lower. Phenols are also defined as compounds produced by plants under stressful conditions, hence the conclusion about the positive effect of the tested biostimulant on strawberries [59]. The foliar spraying of the "Airén" grapevines by non-toasted and toasted biostimulants increased the content of phenolic compounds. In this case, the biostimulants were extracts from the "Moscatel" vine shoots. An important group of phenolic grape buds are hydroxycinnamic acids (trans-caffeic and trans-p-coumaric), which affect the taste of wine. Both non-toasted biostimulants (14.10 \pm 0.13$)$ and toasted biostimulants $(11.26 \pm 0.27)$ led to a trans-p-coumaric acid increase relative to the control $(8.60 \pm 0.03)$. The non-toasted biostimulant $(1.14 \pm 0.01)$ and toasted biostimulant $(0.95 \pm 0.03)$ also led to a trans-caffeic acid growth compared to the control $(0.92 \pm 0.03)$. The effect of the higher content of, among other compounds, hydroxycinnamic acid is a better quality wine [48]. A biostimulant containing A. nodosum seaweed extract increased the phenol content of "Sangiovese" grapes. A $1.5 \mathrm{~kg} / \mathrm{ha}$ dose of biostimulant increased the phenolic content to $1.063 \mathrm{mg} / \mathrm{cm}^{2}$, while the biostimulant in a dose of $3 \mathrm{~kg} / \mathrm{ha}$ increased the phenolic content to $0.951 \mathrm{mg} / \mathrm{cm}^{2}$. The phenol content of the control was $0.753 \mathrm{mg} / \mathrm{cm}^{2}$. The results were statistically significant [55].

The positive effect of biostimulants is also based on increasing the content of chlorophyll in leaves and thus increasing the efficiency of the process of photosynthesis. Salicylic acid-chitosan nanoparticles used as a biostimulant led to an increase in the content of chlorophyll in leek corn [54]. While the chlorophyll content in the control was $10.72 \mathrm{mg} / \mathrm{g}$, the chlorophyll content in the maize leaves treated with the biostimulant (concentration $0.01 \%-0.16 \%$ ) was in the range of 16.43 to $25.88 \mathrm{mg} / \mathrm{g}$ on average. In plants treated only with chitosan and salicylic acid, a decrease in the chlorophyll content to an average of $9.24 \mathrm{mg} / \mathrm{g}$ and $9.79 \mathrm{mg} / \mathrm{g}$ was observed [54]. After the foliar application of the Moringa oleifera leaf extract, a $34.6 \%$ increase in the chlorophyll content of Cucurbita pepo L. leaves was recorded compared to the control (plants sprayed only with water) [50]. The increase in the chlorophyll content combined with the increased intensity of the photosynthesis process was noted during the cultivation of Hibiscus treated with biostimulants formed in the process of the hydrolysis of waste. A $15 \%$ increase in the chlorophyll content of leaves resulted in a $24 \%$ increase in the photosynthesis rate compared to the control [62].

During the tests to determine the chemical composition of fruits, the content of glucose, fructose, sucrose, ascorbate, proteins, and macro- and micro-elements is often determined. Plants treated with one of the tested biostimulators (arbuscular mycorrhizal fungi + Pseudomonas sp. 19 Fv1T and P. fluorescens C7) showed an increase in the concentration of glucose in tomatoes at $11.83 \mathrm{~g} / \mathrm{kg}$, while in controls the content of glucose was $10.45-11.0 \mathrm{~g} / \mathrm{kg}$. After using this biostimulant, the fructose 
content also increased to about $12.86 \mathrm{~g} / \mathrm{kg}$, while in the controls it was $10.77-11.14 \mathrm{~g} / \mathrm{kg}$. After using a biostimulator based on $A$. nodosum seaweed extract and a silicon extract, a slight increase in the level of sugars in the strawberry fruit was observed. The most common sugars were glucose and fructose. Sucrose accounted for $11 \%$ of total sugars [59]. The use of an extract of $M$. oleifera leaves increased the total soluble sugar content in pumpkin by about $80.6 \%$ [50]. An interesting relationship was observed in the case of ascorbate. The use of biostimulant containing arbuscular mycorrhizal fungi, Pseudomonas sp. $19 \mathrm{Fv} 1 \mathrm{~T}$ and $P$. fluorescens $\mathrm{C} 7$ led to an increase in the ascorbate content $(10.75 \mathrm{mg} / 100 \mathrm{~g})$, whereas the use of a biostimulant containing arbuscular mycorrhizal fungi and P. fluorescens $\mathrm{C} 7$ reduced the ascorbate content in tomatoes $(4.30 \mathrm{mg} / 100 \mathrm{~g})$. In the controls, tomatoes contained about $5.47-7.12 \mathrm{mg} / 100 \mathrm{~g}$ ascorbate. In plants treated with the biostimulant containing arbuscular mycorrhizal fungi and P. fluorescens C7, an increase in $\beta$-carotene in tomatoes was observed (controls: $2.117-2.224 \mu \mathrm{g} / 100 \mathrm{~g}$ fresh weight; $\beta$-carotene content in the biostimulator study: $2.829 \mu \mathrm{g} / 100 \mathrm{~g}$ fresh weight). $\beta$-carotene may be converted into vitamin A and can protect against the adverse effects of free radicals [53]. The protein content is particularly important in the case of grain plants. The foliarly used biostimulator containing sewage sludge caused an increase in protein content in maize grains by about $30 \%$ in both growing seasons [45]. The biostimulator formed as a by-product of the two-stage process of pressing olive oil led to an increase in the protein content of maize grains by $19 \%$ [63].

Combining the biostimulant (chicken feathers) with a fertilizer gave a better quality of maize yield than using only the fertilizer. Three combinations of the agent used for spraying the corn were used. In the first variant, only fertilizer was used ( $300 \mathrm{~kg} \mathrm{~N} / \mathrm{ha}+120 \mathrm{~kg} \mathrm{~K} / \mathrm{ha})$. For the second variant, fertilizer was used ( $300 \mathrm{~kg} \mathrm{~N} / \mathrm{ha}+120 \mathrm{~kg} \mathrm{~K} / \mathrm{ha}$ ) in combination with a biostimulant (3.6 L/ha). In the third variant, fertilizer ( $300 \mathrm{~kg} \mathrm{~N} / \mathrm{ha}+120 \mathrm{~kg} \mathrm{~K} / \mathrm{ha}$ ) was used in combination with a biostimulant (7.2 L/ha). The treatment was applied during two seasons. The highest level of nitrogen was obtained after the application of a biostimulant containing fertilizer in combination with the highest dose of the biostimulant ( $7.2 \mathrm{~L} / \mathrm{ha}$ ). The nitrogen content of corn leaves increased by $14.4 \%$ (fertilizer with the biostimulant of $3.6 \mathrm{~L} / \mathrm{ha}$ ) and $39.1 \%$ (fertilizer with the biostimulant of $7.2 \mathrm{~L} / \mathrm{ha}$ ) in the first vegetative season in comparison to the nitrogen content of maize leaves treated only with fertilizer. In the second growing season, the nitrogen content increased by $15 \%$ (fertilizer with the biostimulant of $3.6 \mathrm{~L} / \mathrm{ha}$ ) and $33.3 \%$ (fertilizer with the biostimulant of $7.2 \mathrm{~L} / \mathrm{ha}$ ) respectively. The use of a biostimulant in combination with the fertilizer also resulted in an increase in phosphorus content in the leaves of maize. The treatment increased $p$ levels by $32.8 \%$ (fertilizer with a biostimulant of $3.6 \mathrm{~L} / \mathrm{ha}$ ) and $52.2 \%$ (fertilizer with a biostimulant $7.2 \mathrm{~L} / \mathrm{ha}$ ) in the first season and by $43.5 \%$ (fertilizer with a biostimulant of $3.6 \mathrm{~L} / \mathrm{ha}$ ) and $51.1 \%$ (fertilizer with a biostimulant of $7.2 \mathrm{~L} / \mathrm{ha}$ ) in the second season compared to the control [33]. An effective biostimulant for the "Kinnow" mandarin trees proved to be Moringa oleifera extract. The $3 \%$ Moringa oleifera extract foliar application with $0.6 \% \mathrm{ZnSO}_{4}$ and $0.25 \% \mathrm{~K}_{2} \mathrm{SO}_{4}$ resulted in a 1.35-fold (first season) and 1.42-fold (second season) increase in nitrogen content compared to the control. Trees sprayed only with 3\% Moringa oleifera extract showed a 1.09 times (first season) and 1.07 times (second season) higher phosphorus content compared to control trees [51].

The improvement in the chemical properties of fruits may increase not only their pro-health values, but also lead to an improvement in their sensory values. One example may be guaiacol, which was applied in a foliar way to improve the quality of wine. Guaiacol was shown to increase the amount of glycosylated aromatic compounds in "Microvine" grapes. These compounds have influenced the improvement of wine quality in the final step of wine formation. The guaiacol-treated fruits were characterized by a higher aglycone content $(534.25 \mu \mathrm{g} / \mathrm{g})$ compared to the control $(157.52 \mu \mathrm{g} / \mathrm{g})$. Treatment with guaiacol also increased the content of monomethyl alcohols from $2.94 \mu \mathrm{g} / \mathrm{g}$ in control fruits to $170.30 \mu \mathrm{g} / \mathrm{g}$ in guaiacol-treated fruits [64].

Biostimulants are becoming a viable option for solving the problem of the ineffective uptake of nutrients from fertilizers by plants. The fact is that a large proportion of fertilizer nutrients are not taken up by plants. Reducing the amount of mineral fertilizers introduced into the soil limits environmental degradation. It is thought that the development of certain biostimulants has the potential to increase 
the amount of nutrients taken up by plants [65]. The increase in the amount of nutrients taken up by plants may be achieved through the use of fertilizers and biostimulants in combination [33]. An increased nitrogen content was obtained thanks to the use of a biostimulant formed in the process of the hydrolysis of chicken feathers in combination with nitrogen fertilizer, while the increase in phosphorus content was the result of using a biostimulant formed in the process of the hydrolysis of chicken feathers with phosphate fertilizer [33] and an extract of Moringa oleifera as a biostimulant [51].

\section{Effect of Biostimulants on Antioxidant Properties}

Antioxidant activity is an often-studied property of fruits and vegetables. Antioxidants are listed as compounds that inhibit tumour cell proliferation and protect against oxidative stress caused by excess free radicals. The result of oxidative stress may be, among other factors, damage to DNA, cell membranes, or enzymes [66]. It was shown that the use of biostimulants in plant breeding can change the activity of enzymes and affect the antioxidant properties. Lycopene, ascorbic acid, phenolic compounds and others have antioxidant properties. Reactive oxygen molecules, e.g., $\mathrm{OH}$, $\mathrm{O}^{2-}$, and $\mathrm{H}_{2} \mathrm{O}_{2}$, are detoxified by antioxidant compounds (e.g., phenols, ascorbic acid) and enzymes (e.g., catalase, peroxidase, superoxide dismutase) [67].

Protein hydrolysate applied as a biostimulant to tomatoes had no effect on the level of phenolic compounds, while its effect on the content of ascorbic acid and lycopene was noted. After using biostimulant doses of 5.0 and $2.5 \mathrm{~mL} / \mathrm{L}$, the content of lycopene increased by $34.9 \%$ and $18.0 \%$, respectively, compared to the control. The dose of $2.5 \mathrm{~mL} / \mathrm{L}$ biostimulant increased the content of ascorbic acid by $27.3 \%$ [68]. The use of biostimulants on apricot fruit trees increased the antioxidant capacity of fruits. In the first season (average $76.8 \mathrm{mg} / 100 \mathrm{~g}$ ), after using the stimulants, the antioxidant capacity of fruit was higher than in the second season (average $66.5 \mathrm{mg} / 100 \mathrm{~g}$ ). The observed differences in antioxidative abilities between the two seasons were explained by changes in climatic conditions [8].

Also, a biostimulant based on salicylic acid and chitosan nanoparticles (SA-CS NPs) had an effect on the enzyme and antioxidant activity in maize leaves. The enzyme activity in leaves treated with chitosan, salicylic acid, and a control was comparable. After two days of treating the plants with the biostimulant, the activity of superoxide dismutase increased by two times compared to plants treated with salicylic acid. After three days of treating plants with a biostimulant, superoxide dismutase activity was 3.2 times higher than for plants treated with only salicylic acid. Peroxidase activity in plants treated with a biostimulant was 7.7 (after two days) and 5.2 (after three days) times higher than for plants treated with only salicylic acid. Catalase activity, phenylalanine ammonia lyase, and polyphenol oxidase increased by 2.9, 2.3, and 1.5-fold, respectively, after the second day of treatment with nanoparticles compared to salicylic acid treatment. It should be emphasized that the enzyme activity occurring in the leaves of plants treated with a biostimulant increased during the first three days. After the fourth day of treatment, the enzyme activity decreased in all variants of the experiment. The content of hydrogen peroxide in leaves treated with SA-CS NPs was 1.7 (first day of treatment), 3.6 (second day of treatment), and 1.7 (third day of treatment) times higher than in plants treated with salicylic acid [54].

The use of M. oleifera extract as a biostimulant resulted in a decrease in the activity of the antioxidant enzymes (catalase, peroxidase, and superoxide dismutase) in rocket plants (Eruca vesicaria subsp. Sativa). At the same time, the content of phenol and ascorbic acid was higher with increasing concentrations of the biostimulant [67]. Aqueous garlic extract improved tomato oxidation properties. Superoxide dismutase activity increased in proportion to the aqueous garlic extract concentration. The highest activity of this enzyme was observed with the foliar application of the biostimulant in a volume of $200 \mu \mathrm{g} / \mathrm{L}$; also, the peroxidase activity was highest after using the biostimulant at this concentration. A lower aqueous garlic extract concentration $(50 \mu \mathrm{g} / \mathrm{L})$ did not affect the activity of these enzymes [69]. Soaking sunflower seed Helianthus annuus L. in a 3\% corn seed extract and spraying $1 \mathrm{mM} \mathrm{Mg}$ plants stimulated the sunflower's antioxidant system. The enzymatic activity of superoxide dismutase, catalase, and peroxidase increased by $65.5 \%, 77.8 \%$, and $84.6 \%$, respectively, as compared 
to the controls. The increased level of antioxidant enzymes was related to the foliar application of $\mathrm{Mg}$ ions, the use of which also increased the intensity of the photosynthesis process [56].

Biostimulants increased the phenylalanine ammonia lyase enzyme activity. While the phenylalanine ammonia lyase level in the control was $7.9 \pm 0.22 \mathrm{IU} / \mathrm{mL} \times \min (0.4 \%$ E. maxima extract), after using biostimulants it increased to $9.0 \pm 0.01$ and $9.7 \pm 0.01 \mathrm{IU} / \mathrm{mL} \times \min (10-6 \mathrm{M}$ E. maxima extract). Phenylalanine ammonia lyase is an enzyme catalyzing the first step in the synthesis of phenyl compounds. An increased production of phenolic compounds is observed during plant stress. From this, it may be concluded that biostimulants can induce plant stress to increase the production of secondary metabolites [70]. Biostimulatory properties also reveal many components of compost. Depending on the raw materials and methods used for the composting process, the compost may contain, among others, polysaccharides, amino acids, and organic nitrogen. Compost can be used to replace peat in greenhouse cultures. In addition, it may be produced from organic waste, such as wood, plant residue, or other residues. Compost which is considered by the European Union to be ecological must consist solely of natural raw materials, characterized by a limited content of heavy metals and hazardous elements (Se, Mo, S). The product of the composting process must be free of pathogenic agents (Salmonella sp. and Escherichia coli) [71]. Agroindustrial compost proved to be an alternative to peat in the cultivation of red lettuce. The compost increased the content of antioxidant compounds in lettuce leaves. In the autumn season, lettuce leaves cultivated in the compost showed 1.5 times more antioxidant activity than lettuce grown in compost in the summer season and it was also higher that of lettuce grown in peat in the autumn season [72].

\section{Conclusions}

Biostimulants are preparations of natural origin that support the pro-ecological cultivation of vegetables and fruits. Although for several years a positive effect of biostimulants has been widely reported, they are rarely introduced into standard cultivation technologies. This is connected with the insufficient knowledge of farmers on functions and usage of biostimulants what results in a fear of an increase in the cost of cultivation and a reduction in the quality and quantity of plants, which would affect the profitability of crops. The problem is also the multitude of preparations and the need to select a proper biostimulant for a specific plant variety in order to obtain the highest and the best quality yields. The market requires the development of preparations with a broad spectrum of functionality, which is easy to apply and has the possibility of combination with other agents.

The use of biostimulants on a commercial scale would limit the amount of mineral fertilizers introduced into the environment, thus reducing the pollution of soils, water, and air. This is especially important in the case of global warming. Global agriculture accounts for an average of $21 \%$ [73] of the global greenhouse effect, of which around 13\% [74] is concerned with the effect of artificial fertilizers. The newly developed technologies of biopreparations may constitute a significant contribution to environmental protection, but primarily they are closely linked with sustainable agricultural and horticultural production with the aim of obtaining cheap, easily available, and high quality food. The effect of biostimulants depends on many factors, from the raw material and the process as a result of which they arose to the plant varieties, application method, and climate. The positive effect of consortia of microorganisms and plant hydrolysates on growth and yield of crops plants should be particularly emphasized. It is also important to increase the antioxidant potential of plants treated with biostimulants containing algae. A positive impact on crop quality and performance, no negative or harmful impact on people, animals, or the environment, increased biodiversity of beneficial microorganisms, and improvement of soil properties are the main advantages of biostimulants. However, the nature of their positive influence is not fully understood, therefore their mechanisms of action are, in some cases, still a challenge and need to be recognized. For this reason, biostimulants are among the hot topics in agriculture and still require detailed research. 
Author Contributions: M.D. collected the data, interpreted the results and wrote the manuscript. M.F. provided ideas and performed reviews and corrections of the manuscript. J.C. designed the study, helped draft the manuscript, interpreted results and corrected the text. All authors read and approved the final manuscript.

Funding: The National Centre for Research and Development, Poland, project BIOSTRATEG, contract number BIOSTRATEG3/344433/16/NCBR/2018.

Conflicts of Interest: The authors declare no conflict of interest.

\section{References}

1. Di Vittori, L.; Mazzoni, L.; Battino, M.; Mezzetti, B. Pre-Harvest Factors Influencing the Quality of Berries. Sci. Hortic. 2018, 233, 310-322. [CrossRef]

2. European Union. II Non-Legislative Acts. DECISIONS: Commission Implementing Decision (EU) 2017/1442 of 31 July 2017 Establishing Best Available Techniques (BAT) Conclusions, under Directive 2010/75/EU of the European Parliament and of the Council, for Large Combustion Pl. Off. J. Eur. Union. L 2017, 60, 1-88.

3. Møller, A.P.; Laursen, K. Reversible Effects of Fertilizer Use on Population Trends of Waterbirds in Europe. Biol. Conserv. 2015, 184, 389-395. [CrossRef]

4. Rouphael, Y.; Spichal, L.; Panzarova, K.; Casa, R.; Colla, G. High-Throughput Plant Phenotyping for Developing Novel Biostimulants: From Lab to Field or from Field to Lab? Front. Plant Sci. 2018, 9, 1-19. [CrossRef] [PubMed]

5. Rouphael, Y.; Colla, G. Synergistic Biostimulatory Action: Designing the Next Generation of Plant Biostimulants for Sustainable Agriculture. Front. Plant Sci. 2018, 9, 1-24. [CrossRef]

6. Bradshaw, T.L.; Berkett, L.P.; Griffith, M.C.; Darby, H.M.; Moran, R.E.; Garcia, M.E. Assessment of Kelp Extract Biostimulants on Tree Growth, Yield, and Fruit Quality in a Certified Organic Apple Orchard. In II International Organic Fruit Symposium 1001; International Society for Horticultural Science: Brabant, Belgium, 2013; pp. 191-198. [CrossRef]

7. Kyriacou, M.C.; Rouphael, Y. Towards a New Definition of Quality for Fresh Fruits and Vegetables. Sci. Hortic. 2018, 234, 463-469. [CrossRef]

8. Tarantino, A.; Lops, F.; Disciglio, G.; Lopriore, G. Effects of Plant Biostimulants on Fruit Set, Growth, Yield and Fruit Quality Attributes of 'Orange Rubis ${ }^{\circledR}$ ' Apricot (Prunus armeniaca L.) Cultivar in Two Consecutive Years. Sci. Hortic. 2018, 239, 26-34. [CrossRef]

9. The European Parliament and the Council of the European Union. Regulation (Eu)/Laying down Rules on the Making Available on the Market of EU Fertilising Products and Amending Regulations (EC) No 1069/2009 and (EC) No 1107/2009 and Repealing Regulation (EC) No 2003/2003; European Commission: Brussels, Belgium, 2019; Volume 0270.

10. du Jardin, P. Plant Biostimulants: Definition, Concept, Main Categories and Regulation. Sci. Hortic. 2015, 196, 3-14. [CrossRef]

11. Chiaiese, P.; Corrado, G.; Colla, G.; Kyriacou, M.C.; Rouphae, Y. Renewable Sources of Plant Biostimulation: Microalgae as a Sustainable Means to Improve Crop Performance. Front. Plant Sci. 2018, 9, 1-6. [CrossRef]

12. Battacharyya, D.; Babgohari, M.Z.; Rathor, P.; Prithiviraj, B. Seaweed Extracts as Biostimulants in Horticulture. Sci. Hortic. 2015, 196, 39-48. [CrossRef]

13. Colla, G.; Nardi, S.; Cardarelli, M.; Ertani, A.; Lucini, L.; Canaguier, R.; Rouphael, Y. Protein Hydrolysates as Biostimulants in Horticulture. Sci. Hortic. 2015, 196, 28-38. [CrossRef]

14. Colla, G.; Rouphael, Y.; Di Mattia, E.; El-Nakhel, C.; Cardarelli, M. Co-Inoculation of Glomus Intraradices and Trichoderma Atroviride Acts as a Biostimulant to Promote Growth, Yield and Nutrient Uptake of Vegetable Crops. J. Sci. Food Agric. 2015, 95, 1706-1715. [CrossRef] [PubMed]

15. Mukherjee, P.K.; Horwitz, B.A.; Herrera-Estrella, A.; Schmoll, M.; Kenerley, C.M. Trichoderma Research in the Genome Era. Annu. Rev. Phytopathol. 2013, 51, 105-129. [CrossRef] [PubMed]

16. Nicolás, C.; Hermosa, R.; Rubio, B.; Mukherjee, P.K.; Monte, E. Trichoderma Genes in Plants for Stress Tolerance-Status and Prospects. Plant Sci. 2014, 228, 71-78. [CrossRef] [PubMed]

17. Usuki, F.; Narisawa, K. A Mutualistic Symbiosis between a Dark Septate Endophytic Fungus, Heteroconium Chaetospira, and a Nonmycorrhizal Plant, Chinese Cabbage. Mycologia 2007, 99, 175-184. [CrossRef] [PubMed] 
18. Gaiero, J.R.; McCall, C.A.; Thompson, K.A.; Day, N.J.; Best, A.S.; Dunfield, K.E. Inside the Root Microbiome: Bacterial Root Endophytes and Plant Growth Promotion. Am. J. Bot. 2013, 100, 1738-1750. [CrossRef] [PubMed]

19. Zhao, D.; Zhao, H.; Zhao, D.; Zhu, X.; Wang, Y.; Duan, Y.; Xuan, Y.; Chen, L. Isolation and Identification of Bacteria from Rhizosphere Soil and Their Effect on Plant Growth Promotion and Root-Knot Nematode Disease. Biol. Control 2018, 119, 12-19. [CrossRef]

20. Tavarini, S.; Passera, B.; Martini, A.; Avio, L.; Sbrana, C.; Giovannetti, M.; Angelini, L.G. Plant Growth, Steviol Glycosides and Nutrient Uptake as Affected by Arbuscular Mycorrhizal Fungi and Phosphorous Fertilization in Stevia Rebaudiana Bert. Ind. Crops Prod. 2018, 111, 899-907. [CrossRef]

21. Souri, M.K.; Bakhtiarizade, M. Scientia Horticulturae Biostimulation Effects of Rosemary Essential Oil on Growth and Nutrient Uptake of Tomato Seedlings. Sci. Hortic. 2019, 243, 472-476. [CrossRef]

22. Ugolini, L.; Cinti, S.; Righetti, L.; Stefan, A.; Matteo, R.; D'Avino, L.; Lazzeri, L. Production of an Enzymatic Protein Hydrolyzate from Defatted Sunflower Seed Meal for Potential Application as a Plant Biostimulant. Ind. Crops Prod. 2015, 75, 15-23. [CrossRef]

23. Scaglia, B.; Pognani, M.; Adani, F. The Anaerobic Digestion Process Capability to Produce Biostimulant: The Case Study of the Dissolved Organic Matter (DOM) vs. Auxin-like Property. Sci. Total Environ. 2017, 589, 36-45. [CrossRef] [PubMed]

24. Pacholczak, A.; Szydo, W.; Jacygrad, E.; Federowicz, M. Effect of auxins and the biostimulator algaminoplant on rhizogenesis in stem cuttings of two dogwood cultivars (Cornus alba "Aurea" and 'Elegantissima'). Hortorum Cultus 2012, 11, 93-103.

25. Xu, C.; Leskovar, D.I. Effects of A. nodosum Seaweed Extracts on Spinach Growth, Physiology and Nutrition Value under Drought Stress. Sci. Hortic. 2015, 183, 39-47. [CrossRef]

26. Spann, T.M.; Road, E.S.; Alfred, L.; Little, H.A. Applications of a Commercial Extract of the Brown Seaweed Ascophyllum Nodosum Increases Drought Tolerance in Container-Grown 'Hamlin' Sweet Orange Nursery Trees. HortScience 2011, 46, 577-582. [CrossRef]

27. Hernández-Herrera, R.M.; Santacruz-ruvalcaba, F.; Ruiz-lópez, M.A.; Norrie, J.; Hernández-Carmona, G. Effect of Liquid Seaweed Extracts on Growth of Tomato Seedlings (Solanum lycopersicum L.). J. Appl. Phycol. 2014, 619-628. [CrossRef]

28. Kumari, R.; Kaur, I.; Bhatnagar, A.K. Effect of Aqueous Extract of Sargassum Johnstonii Setchell \& Gardner on Growth, Yield and Quality of Lycopersicon Esculentum Mill. J. Appl. Phycol. 2011, 623-633. [CrossRef]

29. Dias, M.P.; Bastos, M.S.; Xavier, V.B.; Cassel, E.; Astarita, L.V.; Santarém, E.R. Plant Growth and Resistance Promoted by Streptomyces Spp. in Tomato. Plant Physiol. Biochem. 2017, 118, 479-493. [CrossRef] [PubMed]

30. Zhao, L.F.; Xu, Y.J.; Lai, X.H. Antagonistic Endophytic Bacteria Associated with Nodules of Soybean (Glycine $\max$ L.) and Plant Growth-Promoting Properties. Braz. J. Microbiol. 2018, 49, 269-278. [CrossRef]

31. Lamont, J.R.; Wilkins, O.; Bywater-Ekegärd, M.; Smith, D.L. From Yogurt to Yield: Potential Applications of Lactic Acid Bacteria in Plant Production. Soil Biol. Biochem. 2017, 111, 1-9. [CrossRef]

32. Morales-Payan, J.P. Influence of Foliar Sprays of an Amino Acid Formulation on Fruit Yield of "Edward" Mango. Acta Hortic. 2015, 1075, 157-160. [CrossRef]

33. Tejada, M.; Rodríguez-Morgado, B.; Paneque, P.; Parrado, J. Effects of Foliar Fertilization of a Biostimulant Obtained from Chicken Feathers on Maize Yield. Eur. J. Agron. 2018, 96, 54-59. [CrossRef]

34. Ramírez-Pérez, L.J.; Morales-Díaz, A.B.; Benavides-Mendoza, A.; De-Alba-Romenus, K.; González-Morales, S.; Juárez-Maldonado, A. Dynamic Modeling of Cucumber Crop Growth and Uptake of N, P and K under Greenhouse Conditions. Sci. Hortic. 2018, 234, 250-260. [CrossRef]

35. Panfili, I.; Bartucca, M.L.; Del Buono, D. The Treatment of Duckweed with a Plant Biostimulant or a Safener Improves the Plant Capacity to Clean Water Polluted by Terbuthylazine. Sci. Total Environ. 2018, 646, 832-840. [CrossRef] [PubMed]

36. García-Martínez, A.M.; Díaz, A.; Tejada, M.; Bautista, J.; Rodríguez, B.; Santa María, C.; Revilla, E.; Parrado, J. Enzymatic Production of an Organic Soil Biostimulant from Wheat-Condensed Distiller Solubles: Effects on Soil Biochemistry and Biodiversity. Process Biochem. 2010, 45, 1127-1133. [CrossRef]

37. Milić, B.; Tarlanović, J.; Keserović, Z.; Magazin, N.; Miodragović, M.; Popara, G. Bioregulators Can Improve Fruit Size, Yield and Plant Growth of Northern Highbush Blueberry (Vaccinium corymbosum L.). Sci. Hortic. 2018, 235, 214-220. [CrossRef] 
38. Goñi, O.; Quille, P.; O'connell, S. Ascophyllum Nodosum Extract Biostimulants and Their Role in Enhancing Tolerance to Drought Stress in Tomato Plants. Plant Physiol. Biochem. 2018. [CrossRef]

39. Xavier, L.J.C.; Boyetchko, S.M. Arbuscular Mycorrhizal Fungi as Biostimulants and Bioprotectants of Crops. Appl. Mycol. Biotechnol. 2002, 2, 311-340. [CrossRef]

40. Wu, Q.S.; Zou, Y.N.; Fathi Abd-Allah, E. Mycorrhizal Association and ROS in Plants; Elsevier Inc.: Amsterdam, The Netherlands, 2014. [CrossRef]

41. Kocira, A.; Świeca, M.; Kocira, S.; Złotek, U.; Jakubczyk, A. Enhancement of Yield, Nutritional and Nutraceutical Properties of Two Common Bean Cultivars Following the Application of Seaweed Extract (Ecklonia maxima). Saudi J. Biol. Sci. 2018, 25, 563-571. [CrossRef]

42. Filipczak, J.; Żurawicz, E.; Paszt, L.S. Wpływ wybranych biostymulatorów na wzrost i plonowanie roślin truskawki "Elkat" influence of selected biostimulants on the growth and yielding of "Elkat" strawberry plants. Zesz. Naukowe Inst. Ogrod. 2016, 24, 43-58.

43. Kocira, A.; Kocira, S.; Świeca, M.; Złotek, U.; Jakubczyk, A.; Kapela, K. Effect of Foliar Application of a Nitrophenolate-Based Biostimulant on the Yield and Quality of Two Bean Cultivars. Sci. Hortic. 2017, 214, 76-82. [CrossRef]

44. Kocira, S.; Sujak, A.; Kocira, A.; Wójtowicz, A.; Oniszczuk, A. Effect of Fylloton Application on Photosynthetic Activity of Moldavian Dragonhead (Dracocephalum moldavica L.). Agric. Agric. Sci. Procedia 2015, 7, 108-112. [CrossRef]

45. Tejada, M.; Rodríguez-Morgado, B.; Gómez, I.; Franco-Andreu, L.; Benítez, C.; Parrado, J. Use of Biofertilizers Obtained from Sewage Sludges on Maize Yield. Eur. J. Agron. 2016, 78, 13-19. [CrossRef]

46. Rouphael, Y.; Kyriacou, M.C. Quality and Safety of Fresh Fruits and Vegetables at Harvest. Sci. Hortic. 2018, 239, 78-79. [CrossRef]

47. Grajkowski, J.; Ochmian, I. Influence of three biostymulants on yielding and fruit quality of three primocane raspberry cultivars. Hortorum Cultus 2007, 6, 29-36.

48. Sánchez-Gómez, R.; Zalacain, A.; Pardo, F.; Alonso, G.L.; Salinas, M.R. Moscatel Vine-Shoot Extracts as a Grapevine Biostimulant to Enhance Wine Quality. Food Res. Int. 2017, 98, 40-49. [CrossRef] [PubMed]

49. Paradiković, N.; Vinković, T.; Vinković Vrček, I.; Žuntar, I.; Bojić, M.; Medić-Šarić, M. Effect of Natural Biostimulants on Yield and Nutritional Quality: An Example of Sweet Yellow Pepper (Capsicum annuum L.) Plants. J. Sci. Food Agric. 2011, 91, 2146-2152. [CrossRef] [PubMed]

50. Abd El-Mageed, T.A.; Semida, W.M.; Rady, M.M. Moringa Leaf Extract as Biostimulant Improves Water Use Efficiency, Physio-Biochemical Attributes of Squash Plants under Deficit Irrigation. Agric. Water Manag. 2017, 193, 46-54. [CrossRef]

51. Nasir, M.; Sattar, A.; Basra, S.M.A.; Ullah, A. Foliar Application of Moringa Leaf Extract, Potassium and Zinc Influence Yield and Fruit Quality of 'Kinnow' Mandarin. Sci. Hortic. 2016, 210, 227-235. [CrossRef]

52. Fawzy, Z.F. Response of Growth and Yield of Cucumber Plants (Cucumis sativus L.) to Different Foliar Applications of Humic Acid and Bio-Stimulators. Int. Res. J. Appl. Basic Sci. 2012, 6, 630-637.

53. Bona, E.; Todeschini, V.; Cantamessa, S.; Cesaro, P.; Copetta, A.; Lingua, G.; Gamalero, E.; Berta, G.; Massa, N. Combined Bacterial and Mycorrhizal Inocula Improve Tomato Quality at Reduced Fertilization. Sci. Hortic. 2018, 234, 160-165. [CrossRef]

54. Kumaraswamy, R.V.; Kumari, S.; Choudhary, R.C.; Sharma, S.S.; Pal, A.; Raliya, R.; Biswas, P.; Saharan, V. Salicylic Acid Functionalized Chitosan Nanoparticle: A Sustainable Biostimulant for Plant. Int. J. Biol. Macromol. 2019, 123, 59-69. [CrossRef] [PubMed]

55. Frioni, T.; Sabbatini, P.; Tombesi, S.; Norrie, J.; Poni, S.; Gatti, M.; Palliotti, A. Effects of a Biostimulant Derived from the Brown Seaweed Ascophyllum Nodosum on Ripening Dynamics and Fruit Quality of Grapevines. Sci. Hortic. 2018, 232, 97-106. [CrossRef]

56. ur Rehman, H.; Alharby, H.F.; Alzahrani, Y.; Rady, M.M. Magnesium and Organic Biostimulant Integrative Application Induces Physiological and Biochemical Changes in Sun Flower Plants and Its Harvested Progeny on Sandy Soil. Plant Physiol. Biochem. 2018, 126, 97-105. [CrossRef] [PubMed]

57. Queirós, F.; Ribeiro, C.; Vilela, A.; Aires, A.; Barros, A.I.; Schouten, R.; Paula, A.; Gonçalves, B. Scientia Horticulturae Effects of Calcium and Growth Regulators on Sweet Cherry (Prunus avium L.) Quality and Sensory Attributes at Harvest. Sci. Hortic. 2019, 248, 231-240. [CrossRef]

58. Aziz, R.A.; Naira, A.; Moieza, A. Effect of Plant Biostimulants on Fruit Cracking and Quality Attributes of Pomegranate Cv. Kandhari Kabuli. Sci. Res. Essays 2013, 8, 2171-2175. [CrossRef] 
59. Weber, N.; Schmitzer, V.; Jakopic, J.; Stampar, F. First Fruit in Season: Seaweed Extract and Silicon Advance Organic Strawberry (Fragaria $\times$ Ananassa Duch.) Fruit Formation and Yield. Sci. Hortic. 2018, 242, 103-109. [CrossRef]

60. Jämtgård, S.; Näsholm, T.; Huss-Danell, K. Nitrogen Compounds in Soil Solutions of Agricultural Land. Soil Biol. Biochem. 2010, 42, 2325-2330. [CrossRef]

61. Zarzecka, K.; Gugała, M.; Sikorska, A.; Mystkowska, I.; Baranowska, A.; Niewegłowski, M.; Dołega, H. The Effect of Herbicides and Biostimulants on Polyphenol Content of Potato (Solanum tuberosum L.) Tubers and Leaves. J. Saudi Soc. Agric. Sci. 2018. [CrossRef]

62. Massa, D.; Prisa, D.; Montoneri, E.; Battaglini, D.; Ginepro, M.; Negre, M.; Burchi, G. Scientia Horticulturae Application of Municipal Biowaste Derived Products in Hibiscus Cultivation: Effect on Leaf Gaseous Exchange Activity, and Plant Biomass Accumulation and Quality. Sci. Hortic. 2016, 205, 59-69. [CrossRef]

63. Alberola, C.; Lichtfouse, E.; Navarrete, M.; Debaeke, P.; Souchère, V. Agronomy for Sustainable Development. Ital. J. Agron. 2008, 3, 77-78. [CrossRef]

64. Sánchez-gómez, R.; Torregrosa, L.; Zalacain, A.; Ojeda, H.; Bouckenooghe, V.; Schneider, R.; Alonso, G.L.; Salinas, M.R. Scientia Horticulturae Behavior of Glycosylated Aroma Precursors in Microvine Fruits after Guaiacol Foliar Application. Sci. Hortic. 2019, 246, e1-e8. [CrossRef]

65. Halpern, M.; Bar-Tal, A.; Ofek, M.; Minz, D.; Muller, T.; Yermiyahu, U. The Use of Biostimulants for Enhancing Nutrient Uptake; Elsevier Inc.: Amsterdam, The Netherlands, 2015; Volume 130. [CrossRef]

66. Han, M.; Li, G.; Liu, X.; Li, A.; Mao, P.; Liu, P.; Li, H.; Journal, H.P.; Li, G.; Liu, X.; et al. Phenolic Profile, Antioxidant Activity and Anti-Proliferative Activity of Crabapple Fruits. Hortic. Plant J. 2019. [CrossRef]

67. Abdalla, M.M. Boosting the Growth of Rocket Plants in Response to the Application of Moringa oleifera Extracts as a Biostimulant. Life Sci. J. 2014, 11, 1097-8135.

68. Rouphael, Y.; Colla, G.; Giordano, M.; El-Nakhel, C.; Kyriacou, M.C.; De Pascale, S. Foliar Applications of a Legume-Derived Protein Hydrolysate Elicit Dose-Dependent Increases of Growth, Leaf Mineral Composition, Yield and Fruit Quality in Two Greenhouse Tomato Cultivars. Sci. Hortic. 2017, 226, 353-360. [CrossRef]

69. Hayat, S.; Ahmad, H.; Ali, M.; Ren, K.; Cheng, Z. Aqueous Garlic Extract Stimulates Growth and Antioxidant Enzymes Activity of Tomato (Solanum lycopersicum). Sci. Hortic. 2018, 240, 139-146. [CrossRef]

70. Kulkarni, M.G.; Rengasamy, K.R.R.; Pendota, S.C.; Gruz, J.; Plačková, L.; Novák, O.; Doležal, K.; Van Staden, J. Bioactive Molecules Derived from Smoke and Seaweed Ecklonia Maxima Showing Phytohormone-Like Activity in Spinacia oleracea L. New Biotechnol. 2019, 48, 83-89. [CrossRef] [PubMed]

71. López-López, N.; López-Fabal, A. Scientia Horticulturae Compost Based Ecological Growing Media According EU Eco-Label Requirements. Sci. Hortic. 2016, 212, 1-10. [CrossRef]

72. Giménez, A.; Fernández, J.A.; Pascual, J.A.; Ros, M. Scientia Horticulturae an Agroindustrial Compost as Alternative to Peat for Production of Baby Leaf Red Lettuce in a Floating System. Sci. Hortic. 2019, 246, 907-915. [CrossRef]

73. FAO. The State of Food And Agriculture; FAO: Rome, Italy, 2016.

74. FAO. Greenhouse Gas Emissions from Agriculture, Forestry and Other Land Use; FAO: Rome, Italy, 2014.

(C) 2019 by the authors. Licensee MDPI, Basel, Switzerland. This article is an open access article distributed under the terms and conditions of the Creative Commons Attribution (CC BY) license (http://creativecommons.org/licenses/by/4.0/). 